\title{
ДЕМОГРАФІЧНА СИТУАЦІЯ УКРАЇНИ В СИСТЕМІ ВИМІРУ ЛЮДСЬКОГО КАПІТАЛУ ТА ОХОРОНИ ЗДОРОВ'Я
}

\author{
Іртищева Інна Олександрівна \\ доктор економічних наук, професор \\ Національний університет кораблебудування імені адмірала Макарова, (м. Миколаїв, Україна) \\ ORCID: 0000-0002-7025-9857 \\ innauamd@gmail.com
}

Трушлякова Антоніна Борисівна Національний університет кораблебудування імені адмірала Макарова (м. Миколаїв, Україна) ORCID: 0000-0003-1958-3472 management@nuos.edu.ua

Рябець Дмитро Миколайович здобувач

Причорноморський науково-дослідного інститут економіки та інновацій (м. Одеса, Україна) ORCID:0000-0001-8540-1409 management@nuos.edu.ua

Метою статті є проведення аналіз демографрічної ситуації України в системі виміру людського капіталу та охорони здоров'я. Досліджено людський капітал у наукових теоріях соціально-економічного розвитку. Проаналізовано динаміку чисельності постійного населення України за 1991-2018 роки. Здійснено регіональний розріз чисельності наявного населення. Проаналізовано динаміку координаційного навантаження жінок на 1000 чоловіків для сільського населення. Відображено прогнозне зображення статево-вікового розподілу населення України Встановлено, що старіння населення України можливо розглядати як беззаперечний факт і результат об'єктивних демографрічних процесів за рахунок довготривалих структурних змін вікового складу населення у бік переважання питомої ваги людей віком старше 60 років.

Ключові слова: демографрічна ситуація, людський капітал, охорона здоров'я, чисельність населення

DOI: https://doi.org/10.32845/bsnau.2019.4.26

Постановка проблеми. На сучасному етапі розвитку економіка України зазнає сильного впливу глобалізаційних процесів, що відображається на рівні формування людського капіталу та сучасної моделі національного розвитку. Глобальні виклики розглядають людину у центрі всіх суспільних явищ і процесів, а її можливості виступають ресурсним забезпеченням соціально-економічного розвитку. Таким чином, людський капітал розглядають в якості основного фактору розвитку національної економіки. Важливого значення набувають питання інвестування в людський розвиток та подолання соціальних нерівностей. В якості загрозливої ситуації для України необхідно розглядати можливість виключно декларативного проголошення людино центричного розвитку та прикриття байдужого ставлення до задоволення потреб людини та дбайливого використання її здібностей.

Аналіз останніх досліджень та публікацій. Питанням аналізу демографічної ситуації України приділено достатньо багато уваги у працях вітчизняних та зарубіжних дослідників, зокрема А. Колотом [1], С. Мочерним [2], Б. Данилишиним, Л. Чернюком, М. Фащевським [6], І. Дегтярьовою [7], В. Медвідь [8], Т. Приходченко [9], І. Іртищева, О. Гуріна, Ю. Работін [20-21], І. Крамаренко [22] та ін. Однак варто зазначити, що саме особливостям демографічної ситуації України в системі виміру людського капіталу та охорони здоров'я не так і багато досліджень.

Метою статті аналіз демографічної ситуації України в системі виміру людського капіталу та охорони здоров'я.

Виклад основного матеріалу. На сьогоднішній день існує багато наукових доробків присвячених проблемі фрорму- вання та розвитку людського капіталу, як складовій соціально-трудової проблематики. Можливо погодитися із висловлюванням вченого А.Колота, що більшість праць не достатньо розкривають можливості подальшого розвитку людського капіталу та не можуть навіть характеризуватися як повне та всебічне «теоретичне узагальнення та практичне розв'язання наявних соціально-трудових проблем» $[1$, с.16].

Ще до нашої ери, одним з перших на питання людського капіталу звернув увагу ще Арістотель, який ввів поняття «хрематистика» у сенсі наявності власності на майно та характеризував діяльність людини у напрямку задоволення власних потреб [2, с. 719]. Концептуальні передумови розгляду людського капіталу знайшли своє відображення у працях А. Сміта, Д. Рікардо, В. Петті, К. Маркса, А. Маршалла, І. Фішера та ін. Першість у дослідженні основ теорії людського капіталу належить американським вченим Т. Шульцу та Г. Беккеру. «Основними результатами інвестицій в людину, Шульц вважав набуття здібностей людей до праці, їх ефективну творчу діяльність у суспільстві, підтримка здоров'я і т. д. Він вважав, що людський капітал має необхідні ознаками продуктивного характеру. Людський капітал здатний накопичуватися і відтворюватися. За оцінками Шульца, з виробленого в суспільстві сукупного продукту на накопичення людського капіталу використовується вже не $1 / 4$, як випливало з більшості теорій відтворення XX століття, а $3 / 4$ його загальної величини. Гері Беккер, мабуть, першим переніс поняття людського капіталу на мікрорівень. Людський капітал підприємства він визначив як сукупність навичок, знань і умінь людини. Як інвестицій в них Беккер врахував, в основному, витрати на освіту та навчання. Беккер оцінив економічну ефрективність освіти, перш 
за все, для самого працівника. Додатковий дохід від вищої освіти він визначив так. 3 доходів тих, хто закінчив коледж, він віднімав доходи працівників із середньою загальною освітою. Витратами освіти вважалися як прямі, так і альтернативні витрати - втрачений дохід за час навчання. Віддачу від інвестицій в освіту Беккер оцінив як відношення доходів до витрат, отримавши приблизно 12-14\% річного прибутку» [3].

Для розгляду питання людського капіталу у контексті цифровізації економіки, важливим є дослідження К. Маркса присвячені оцінці впливу технологічного розвитку на соціально-економічний стан працівників. К. Маркс негативно висловлювався про заміну людської праці машинною та масовому вивільненню робочої сили, а саме: «на місце окремої машини приходить механічне чудовисько, тіло якого займає цілі фабричні будівлі та демонічна сила якого, спочатку при- хована у гротескно-розмірених рухах його велетенських членів, виривається у гарячково-несамовитому танку незчисленних власних робочих органів» [4, с. 393]. Негативним наслідком технологічного розвитку ставало безробіття та зростання соціальної нерівності між різними верствами населення.

Сучасний етап розвитку інформаційного суспільства характеризує американський дослідник М. Кастельс через категорію «інформаційне (мережеве) суспільство», який переконаний у значній ролі інфрормації та цифрових технологій у формуванні глобальної соціально-економічної системи на підставі врахування особливостей територіальних мережевих логічних інформаційних систем [5].

Розвиток людського капіталу знаходить своє відображення у наукових теоріях соціально-економічного розвитку (рис. 1).

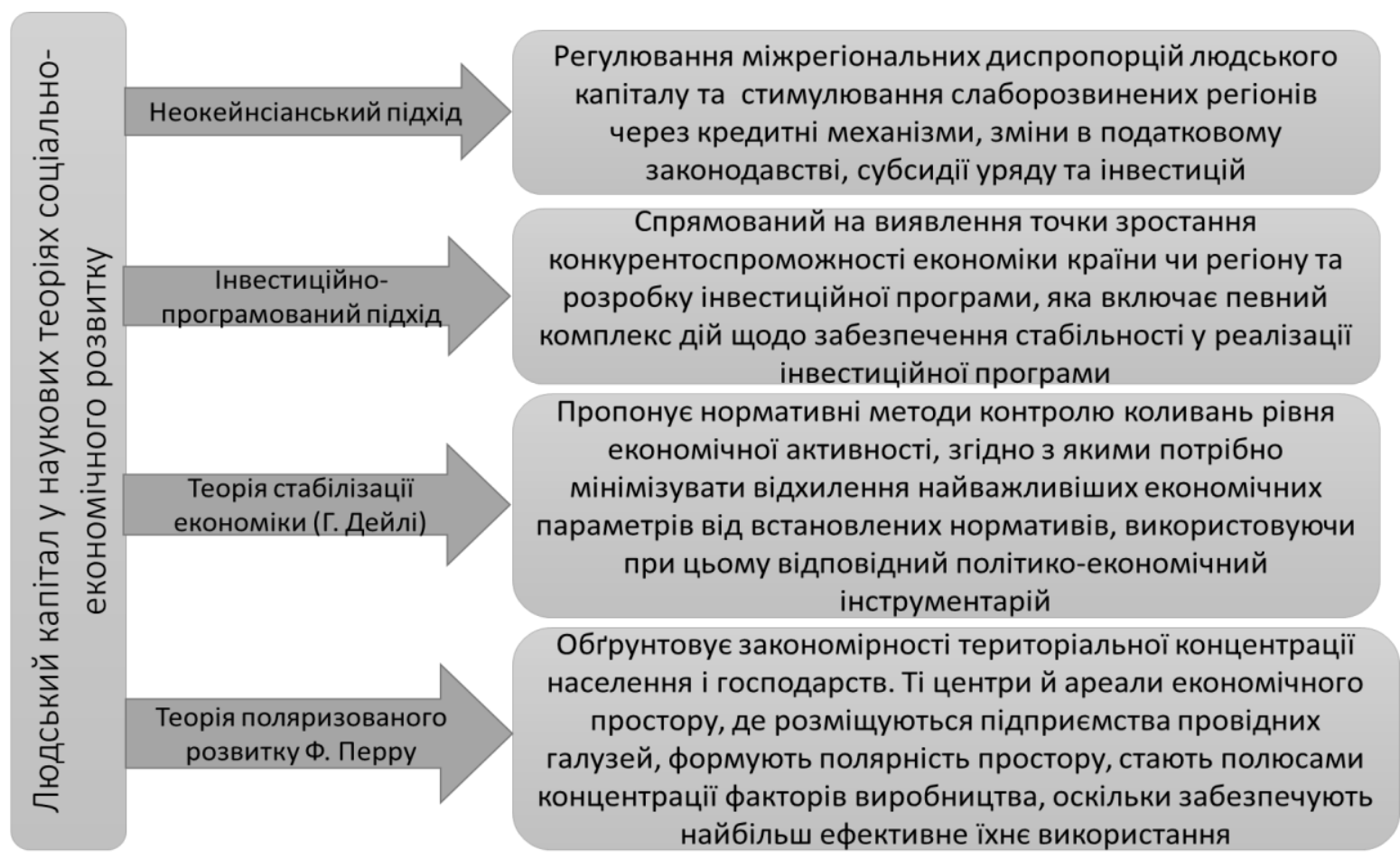

Рис. 1 Відображення людського капіталу у наукових теоріях соціально-економічного розвитку

Джерело: Узагальнено автором на підставі: [6-10]

Людський капітал, як економічна категорія визначається у багатьох економічних словниках, зокрема словник Penguin Dictionary of Economics характеризує людський капітал як «навички, здатність та вміння, які має людина і які дозволяють їй отримувати дохід», що виокремлює здатності людини, які формуються за рахунок інвестицій у людський капітал [11]. Саме визначення категорії людського капіталу обґрунтовується не тільки у економічних словниках та науковцями, а і різними міжнародними організаціями (рис. 2), що в черговий раз доводить важливість використання даного поняття для окреслення шляхів розвитку національної економіки.

Міжнародні інституції найчастіше «людський капітал» використовують для аналізу людських ресурсів, при цьому характеризують рівень та якість освіти громадян, стан здо- ров'я нації, природні процеси відтворення та міграції населення.

Чисельність постійного населення виступає основою дослідження людських ресурсів та людського капіталу нації в цілому та окремих регіонів країни. Саме населення є носіями якісних характеристик людського капіталу, таких як освіта, здоров'я, народжуваність, смертність, зайнятість, безробіття тощо.

Державною службою статистики України категорія «постійне населення» визначається як «населення, яке постійно мешкає на момент перепису на певній території, ураховуючи тимчасово відсутніх, якщо їхня відсутність у місці проживання не перевищувала 12 місяців» [14]. Динаміка чисельності постійного населення України представлена у таблиці 1. 


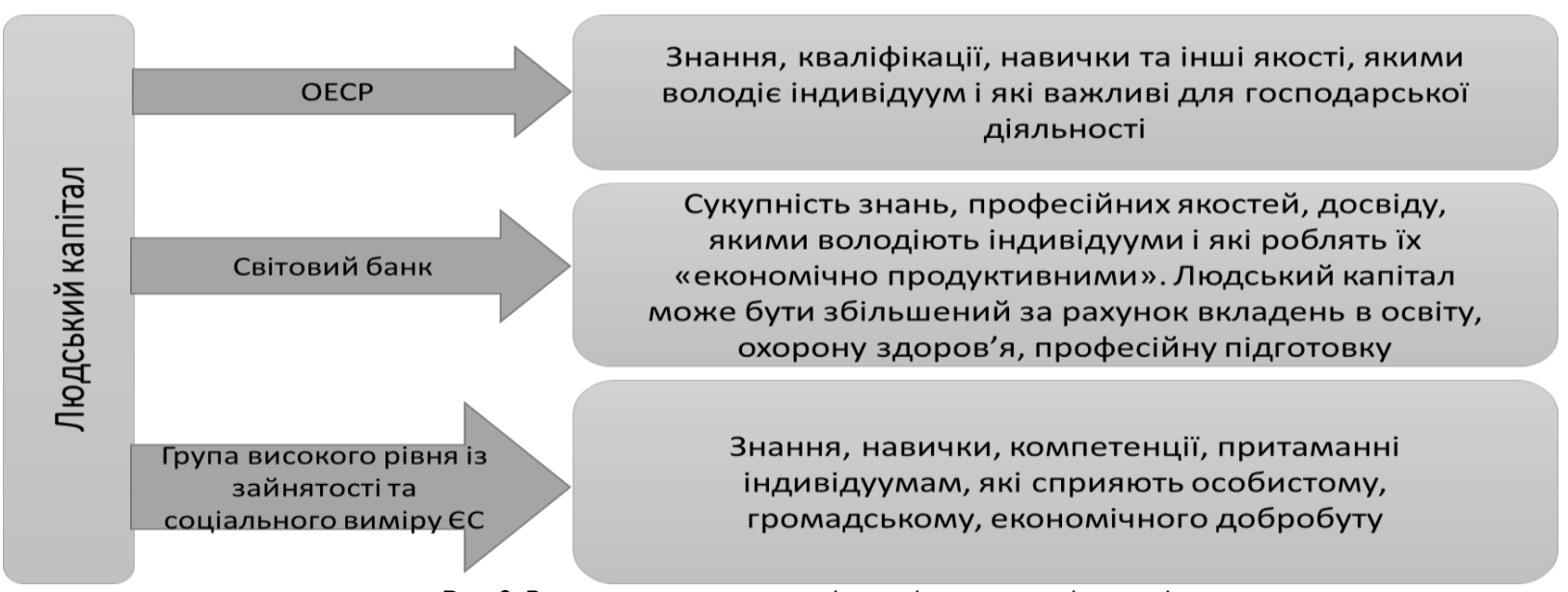

Рис. 2. Визначення людського капіталу міжнародними інституціями

Джерело: Узагальнено автором на підставі: [11-13]

Таблиця 1

Динаміка чисельності постійного населення України за 1991-2018 роки

(на 1 січня)

\begin{tabular}{|c|c|c|c|c|}
\hline & \multicolumn{3}{|c|}{ Ociб } & \multirow{2}{*}{$\begin{array}{c}\text { Ha } 1000 \text { чоловіків припадає } \\
\text { жінок }\end{array}$} \\
\hline & обидві статі & чоловіки & жінки & \\
\hline 1991 & 51623547 & 23886551 & 27736996 & 1161 \\
\hline 1992 & 51708234 & 23949444 & 27758790 & 1159 \\
\hline 1993 & 51870430 & 24046290 & 27824140 & 1157 \\
\hline 1994 & 51715375 & 23981045 & 27734330 & 1157 \\
\hline 1995 & 51300431 & 23792361 & 27508070 & 1156 \\
\hline 1996 & 50874104 & 23591556 & 27282548 & 1156 \\
\hline 1997 & 50400041 & 23366193 & 27033848 & 1157 \\
\hline 1998 & 49973488 & 23163464 & 26810024 & 1157 \\
\hline 1999 & 49544808 & 22963447 & 26581361 & 1158 \\
\hline 2000 & 49114950 & 22754662 & 26360288 & 1158 \\
\hline 2001 & 48663609 & 22530402 & 26133207 & 1160 \\
\hline $2002^{1}$ & 48240902 & 22316317 & 25924585 & 1162 \\
\hline 2003 & 47823108 & 22112534 & 25710574 & 1163 \\
\hline 2004 & 47442079 & 21926809 & 25515270 & 1164 \\
\hline 2005 & 47100462 & 21753993 & 25346469 & 1165 \\
\hline 2006 & 46749170 & 21574667 & 25174503 & 1167 \\
\hline 2007 & 46465691 & 21434680 & 25031011 & 1168 \\
\hline 2008 & 46192309 & 21297678 & 24894631 & 1169 \\
\hline 2009 & 45963359 & 21184932 & 24778427 & 1170 \\
\hline 2010 & 45782592 & 21107067 & 24675525 & 1169 \\
\hline 2011 & 45598179 & 21032616 & 24565563 & 1168 \\
\hline 2012 & 45453282 & 20976712 & 24476570 & 1167 \\
\hline 2013 & 45372692 & 20962744 & 24409948 & 1164 \\
\hline 2014 & 45245894 & 20918288 & 24327606 & 1163 \\
\hline 2015 & 42759661 & 19787826 & 22971835 & 1161 \\
\hline 2016 & 42590879 & 19717881 & 22872998 & 1160 \\
\hline 2017 & 42414905 & 19644580 & 22770325 & 1159 \\
\hline 2018 & 42216766 & 19558180 & 22658586 & 1159 \\
\hline
\end{tabular}

За роки незалежності України, чисельність постійного населення зменшилася майже на 10 мільйонів чоловік, а точніше - на 9639983 чоловік, чисельність чоловічої статі зменшилася на 4431 279, а жінок - на 5208 704. За останні десять років (2010-2018) чисельність постійного населення зменшилася на 3799028 чоловік, чисельність чоловічої статі зменшилася на 1651 759, а жінок - на 2147233.

Таким чином, виявляється тенденція, за кожні десять років зменшення чисельності постійного населення України на понад як 3 мільйони чоловік, що саме по собі є загрозливим явищем.
Що стосується навантаження чисельності жінок на 1000 чоловік, то таке співвідношення не сильно відрізняється з року в рік за своїм числовим вираженням і коливається від 1156 (1995-1996 роки) до 1170 (2009 рік), що є відображенням постійного переважання жіночої статі в структурі населення України. Структурне переважання жіночої статі можливо оцінювати як фактор розширеного відтворення населення, проте очевидною залишається тенденція зменшення загальної чисельності постійного населення України. 
Таблиця 2

Регіональний розріз чисельності наявного населення за 2018 рік

\begin{tabular}{|c|c|c|c|c|c|c|}
\hline & усе населення, осіб & & \multicolumn{2}{|c|}{ Міське, осіб } & \multirow[t]{2}{*}{ Сільське, осіб } & \multirow{3}{*}{ частка регіону, \% } \\
\hline & & \multirow{3}{*}{$\begin{array}{c}\text { частка } \\
\text { регіону, \% }\end{array}$} & & \multirow{3}{*}{$\begin{array}{c}\text { частка } \\
\text { регіону, \% }\end{array}$} & & \\
\hline Україна & 42153201 & & 29256696 & & 12896505 & \\
\hline області & & & & & & \\
\hline Вінницька & 1560394 & 3,70 & 801696 & 2,74 & 758698 & 5,88 \\
\hline Волинська & 1035330 & 2,46 & 540679 & 1,85 & 494651 & 3,84 \\
\hline Дніпропетровська & 3206477 & 7,61 & 2690517 & 9,20 & 515960 & 4,00 \\
\hline Донецька & 4165901 & 9,88 & 3783363 & 12,93 & 382538 & 2,97 \\
\hline Житомирська & 1220193 & 2,89 & 721390 & 2,47 & 498803 & 3,87 \\
\hline Закарпатська & 1256802 & 2,98 & 466138 & 1,59 & 790664 & 6,13 \\
\hline Запорізька & 1705836 & 4,05 & 1319192 & 4,51 & 386644 & 3,00 \\
\hline Івано-Франківська & 1373252 & 3,26 & 606950 & 2,07 & 766302 & 5,94 \\
\hline Київська & 1767940 & 4,19 & 1097273 & 3,75 & 670667 & 5,20 \\
\hline Кіровоградська & 945549 & 2,24 & 597950 & 2,04 & 347599 & 2,70 \\
\hline Луганська & 2151833 & 5,10 & 1872013 & 6,40 & 279820 & 2,17 \\
\hline Львівська & 2522021 & 5,98 & 1537677 & 5,26 & 984344 & 7,63 \\
\hline Миколаївська & 1131096 & 2,68 & 774119 & 2,65 & 356977 & 2,77 \\
\hline Одеська & 2380308 & 5,65 & 1595493 & 5,45 & 784815 & 6,09 \\
\hline Полтавська & 1400439 & 3,32 & 873181 & 2,98 & 527258 & 4,09 \\
\hline Рівненська & 1157301 & 2,75 & 549618 & 1,88 & 607683 & 4,71 \\
\hline Сумська & 1081418 & 2,57 & 747851 & 2,56 & 333567 & 2,59 \\
\hline Тернопільська & 1045879 & 2,48 & 473694 & 1,62 & 572185 & 4,44 \\
\hline Харківська & 2675598 & 6,35 & 2168353 & 7,41 & 507245 & 3,93 \\
\hline Херсонська & 1037640 & 2,46 & 636406 & 2,18 & 401234 & 3,11 \\
\hline Хмельницька & 1264705 & 3,00 & 721997 & 2,47 & 542708 & 4,21 \\
\hline Черкаська & 1206351 & 2,86 & 684002 & 2,34 & 522349 & 4,05 \\
\hline Чернівецька & 904374 & 2,15 & 390719 & 1,34 & 513655 & 3,98 \\
\hline Чернігівська & 1005745 & 2,39 & 655606 & 2,24 & 350139 & 2,71 \\
\hline м.Київ & 2950819 & 7,00 & 2950819 & 10,09 & $\mathrm{x}$ & \\
\hline
\end{tabular}

Джерело: складено та розраховано автором на підставі [14]

Статистичні дані за 2018 рік свідчать про нерівномірний розподіл населення України за регіонами. Так, найбільша частка населення України проживає у Донецькій області (9,88\%), далі йде Дніпропетровська область (7,61\%), далі йде місто Київ (7\%), Харківська область (6,35\%), далі йде Львівська (5,98\%), Одеська (5,65\%), Луганська $(5,1 \%)$ області, а у решти областей питома частка постійного населення не перевищує $5 \%$. Щодо розподілу питомої частки міського населення, то знову лідирує Донецька область, де проживає 12,93\% постійного населення України, далі місто Київ агломерує 10,09\% міського населення, у Дніпропетровській області проживає 9,2\% міського населення, у Харківській - 7,41\%, у Луганській - 6,40\%, у Одеській - 5,45\%, у Львівській $5,26 \%$, а для решти областей відсоткове значення загального розподілу міського населення України не перевищує $5 \%$. Щодо розподілу питомої частки сільського населення, то лідером є Львівська область де проживає 7,63\% сільського населення України, далі йде Закарпатська область - 6,13\% сільського населення України, Івано-Франківська - 5,94\% та Вінницька - 5,88\% сільського населення України.

На рисунку 3 зображено динаміку координаційного навантаження жінок на 1000 чоловіків для сільського населення.

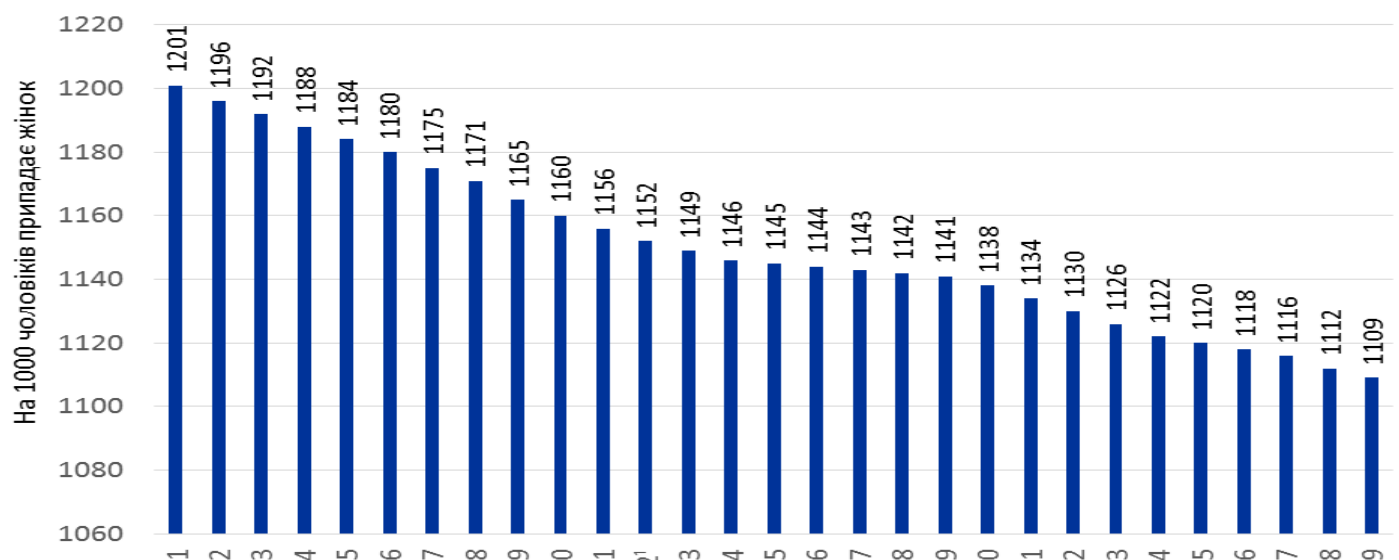

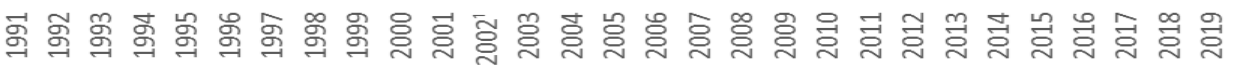

Рис. 3. Динаміка координаційного навантаження жінок на 1000 чоловіків для сільського населення

Джерело: [14] 
Слід зазначити, що якщо в цілому по Україні дані координаційного навантаження жінок на 1000 чоловіків не сильно відрізняються в динаміці 1991-2018 роки, то для сільського населення чітко відслідковується тенденція зменшення кількості жінок у розрахунку на 1000 чоловіків. Так за період 1991-2018 роки показник, що вказує скільки жінок припадає на 1000 чоловіків для сільського населення зменшився на 92.

3 точки зору дослідження відтворення населення важливим $€$ дослідження питання розподілу населення не тільки за статтю, а і за віком (рис.4).

Згідно даних Державної служби статистики України, за 2018 рік у розподілі населення за віковими групами найбільша кількість населення у віці 25-39 років складає 3358614 осіб, далі йде група населення віком 40-44 роки, яка складає 3069863 осіб, далі за чисельністю йде вікова група 55-59 років, яка складає 3110494 осіб, далі йде вікова група 45-49 років (2 907414 осіб), далі вікова група 60-64 роки (2 792559 осіб), потім вікова група 50-54 років (2 743877 осіб), потім вікова група 65-69 років (2 389627 осіб) і тільки потім ідуть вікові групи дитячого віку: 5-9 років (2 372969 осіб), 10-14 років (2 147481 осіб), далі йде вікова група молоді 20-24 рок (2 200523 осіб), а після них йде наймолодша вікова група 0-4 роки (1960 529 осіб).

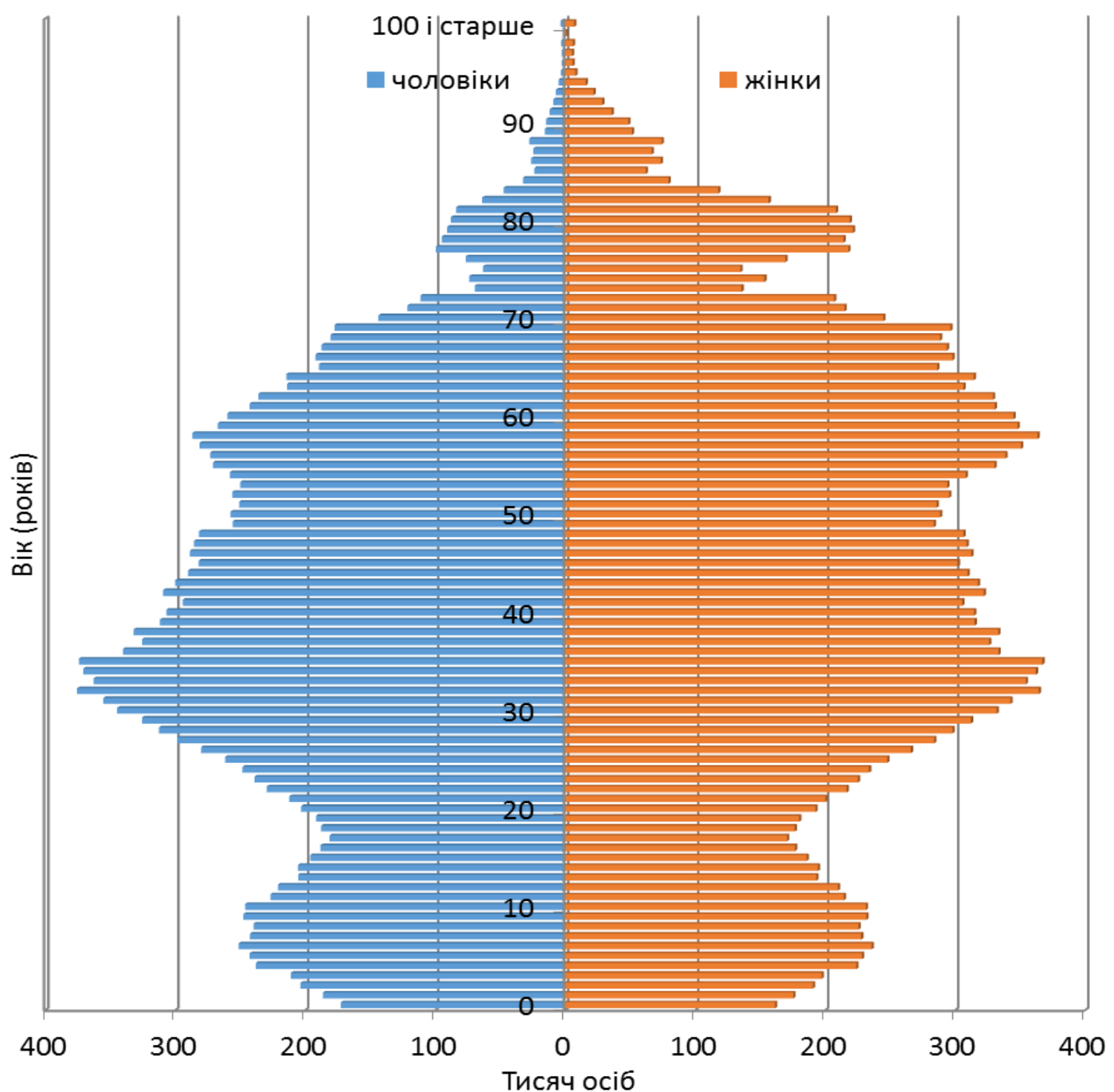

Джерело: [14]

Рис. 4. Графрічне зображення розподілу постійного населення за статтю та віком за 2018 рік

Такий розподіл вікових груп населення свідчить про переважання чисельності вікових груп похилого віку над чисельністю вікових груп дітей, що є загрозливим з точки зору відтворення населення і свідчить про наявність тенденції старіння та загрози вимирання нації. Все це вимагає з боку уряду вимагає розробки програм підтримки народжуваності.
За прогнозом Інституту демографії та соціальних досліджень імені М.В. Птухи НАН України, до 2061 року відбудуться сильні зрушення у віковій структурі населення України у бік збільшення питомої ваги населення віком не менше 60 років до рівня 31,2\% та зменшення питомої ваги дітей до рівня $14,9 \%$ (рис. 5 ). 
2031

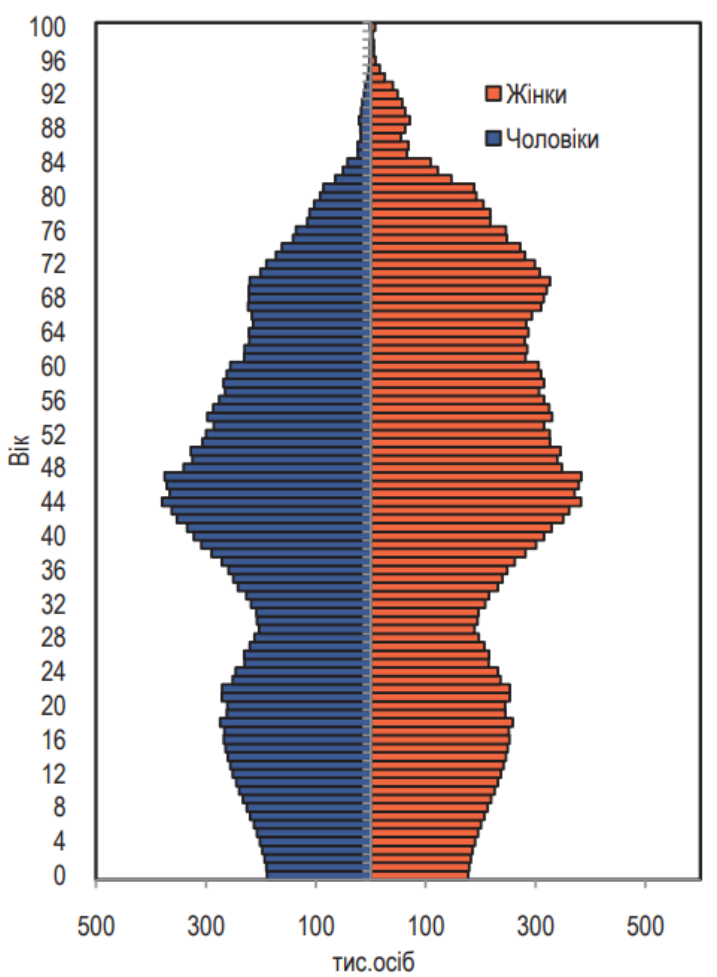

2061

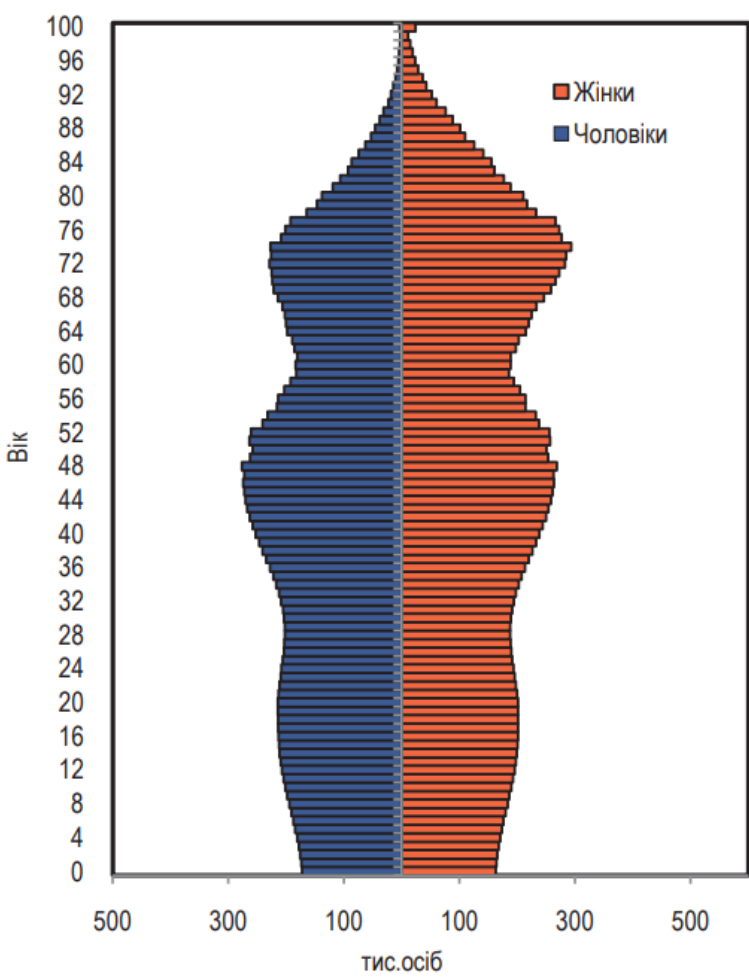

Джерело: [15]

Рис. 5. Прогнозне зображення статево-вікового розподілу населення України

«Вікова структура має тенденцію втратити обриси піраміди, перетворившись на фігуру, схожу на «церковні бані», яка міститиме у своїх контурах три чітко геометрично означені групи (0-28, 29-59 та 60 і старше), частка яких становитиме відповідно 30,2\%, 38,6\% і 31,2\%, тобто осіб у віці 60 років і старше може бути більше, ніж дітей і молоді. Зі стабілізацією вікового складу населення у відповідності з сучасним режимом природного руху, коли чисельність осіб похилого віку збільшуватиметься, вікова піраміда може набути «перекинутого» вигляду, а життєвий і трудовий потенціали - інших, невідомих досі структурних характеристик.» [15]

«3а середнім варіантом прогнозу Інституту демографії та соціальних досліджень імені М.В. Птухи НАН України, до 2061 р. в Україні навантаження літніми людьми на працездатних зросте з $22 \%$ до 45\%, відповідно коесіцієнт потенційної підтримки зменшиться з 4,6 до 2,3. Якщо ж брати вікові рамки працездатного віку не за міжнародним стандартом (15-64 років), а з урахуванням національних юридичних та економічних реалій, віковий інтервал трудової активності звужується до 20-59 років. Через це ситуація виглядає ще більш драматичною: індикатор навантаження (60+ / 20-59), що становить нині $36 \%$, до кінця прогнозованого періоду зросте до 65\%, коефіцієнт потенційної підтримки (20-59 / 60+) -зменшиться $з$ 2,8 до 1,5» [16].

«За прогнозом EUROPOP, темпи подальшого прогресування процесу демограффічного старіння будуть істотно різнитися у країнах «старої» та «нової» Європи. У більш розвинених країнах подальше старіння буде відбуватися набагато повільніше, а в найважчу ситуацію потраплять постсоціалістичні країни Європи, в яких на тлі низької народжуваності і недостатньо високої тривалості життя буде скорочуватися чисельність населення. Якщо в 2010 р. практично за всіма індикаторами рівень старіння в країнах - нових членах ЄС був нижчим від середнього значення, то за наступні 50 років картина кардинально зміниться, і всі вони будуть мати рівень старіння набагато вищий від середнього» $[17,18]$

Французький вчений-дослідник демографрічних процесів Альфред Сові охарактеризував процес старіння нації «найменш спірним, найпростіше вимірюваним, найбільш послідовним у своєму розвитку, найбільш пристосованим для прогнозування i, мабуть, найбільш важким за своїми наслідками» [19].

Основа вікової структурної піраміди населення характеризується чисельність дітей або осіб дитячого віку. За останні десятиріччя дана вікова група населення України переважно скорочувалася, за винятком підвищення народжуваності, що спостерігалося у 2002 році і підсилилася у 2005 році за рахунок введення державної допомоги на народження дитини. Але тенденція зменшення навантаження дітей (0-15 років) та зростання навантаження людей похилого віку (60 років і старше) на населення у віці 16-59 років та 15-64 роки свідчить про майбутнє продовження старіння населення України.

Висновки. Доведено, що старіння населення України можливо розглядати як беззаперечний факт і результат об'єктивних демографрічних процесів за рахунок довготривалих структурних змін вікового складу населення у бік переважання питомої ваги людей віком старше 60 років.

На фоні очевидної тенденції зменшення загальної чисельності населення України у найближчій перспективі буде спостерігатися продовження процесу старіння нації, адже наявна вікова структура у майбутньому буде мати відображення на зростання питомої ваги людей похилого віку. Старіння нації веде до негативних економічних наслідків не тільки за рахунок порівнянного зменшення частки населення працездатного віку, а і за рахунок зростання видатків на пенсійне забезпечення. Тому потрібно прикласти значні зусилля 
для подолання негативних трансформаційних процесів демо-

графрічних структурних змін.

\section{Список використаної літератури:}

1. Колот А.М. Соціально-трудова сфрера в умовах глобальних викликів: тенденції, проблеми, можливості стійкого розвитку. Формування ринкової економіки : зб. наук. праць /спец. вип. у 3 т. 2010. Т. 3. С. 9-22.

2. Економічна енциклопедія : у 3 т. - Т. 1 відп. ред. С.В. Мочерний. К.: Видавничий центр «Академія», 2000. 864 с.

3. Людський капітал. Вікіпедія. URL: https://uk.wikipedia.org/wiki/Людський_капітал

4. Маркс К. Капитал. Критика политической экономии : у 3 т. - Т.1, Кн. I : Процесс производства капитала; под. ред. Ф. Энгельса. М.: Политиздат, 1978. 907 с.

5. Кастельэ М. Информационная эпоха: Экономика, общество и культура. Пер. с англ. под науч. ред. О. И. Шкаратана; Гос. ун-т. Высш. шк. экономики. М. , 2000. 606 с.

6. Данилишин Б.М., Чернюк Л.Г., Фащевський М.І. Просторова організація продуктивних сил України: мезо- та мікрорегіональний рівень. Вінниця: Книга-Вега, 2007. 572 с.

7. Дегтярьова І. Теорії регіонального розвитку та їх еволюція як основа сучасного регіонального управління. Вісн. НАДУ. 2010. № 4. С. 141-148.

8. Медвідь В.Ю. Сучасні концепції та теорії економічного регіонального розвитку. Серія: Економіка та підприємницmво. 2013. № 2(71) C. 66-70.

9. Приходченко Т.А. Теорії та концепції регіонального розвитку. Електронне наукове фрахове видання «Ефективна економіка». 2016. № 9. URL: http://www.economy.nayka.com.ua/?op=1\&z=5149(дата звернення 18.10.2018 року).

10. Perru F. Les techniques quantitatives de la piar Economic et societe. Paris: Economic, 1969.

11. Guide on Measuring Human Capital. Prepared by the Task Force on Measuring Human Capital. - United Nations

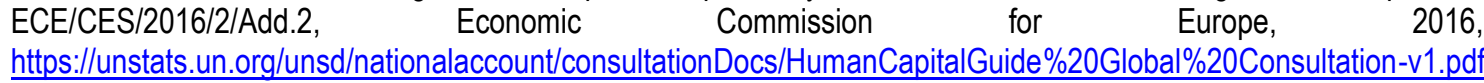

12. The Well-being of Nations: The Role of Human and Social Capital. - OECD, 2001, URL: http://www.oecd.org/site/ worldforum/33703702.pdf. (дата звернення 18.10.2018 року).

13. Измерение человеческого капитала: передовые инициативы и будущие проблемы. - Экономический и Социальный Совет ООН, Европейская экономическая комиссия, Конференция европейских статистиков, 61-я пленарная сессия, Женева, 10-12 июня 2013г., URL: https://www.unece.org/fileadmin/DAM/stats/documents/ece/ ces/2013/5_R_.pdf

14. Демографічний щорічник «Населення України за 2018 рік». Державна служба статистики України. URL: http://www.ukrstat.gov.ua/druk/publicat/kat_u/2019/zb/12/zb_ukr_2018.pdf

15. Населення України: імперативи демографрічного старіння. К.: ВД «АДЕФУкраїна», 2014. 288 с. URL: https://idss.org.ua/monografii/2014_Naselennya.pdf

16. Демографічні прогнози по Україні, 2012 р. Офіційний веб-сайт Інституту демографрії та соціальних досліджень імені M.B. Птухи НАН України (рубрика «Розробки») URL: http://idss.org.ua/monografii/popforecast2012.zip.

17. Giampaolo Lanzieri. The greying of the baby boomers: A century-long view of ageing in European populations. Eurostat. Statistics in focus, Population and social conditions. 2011. 23. 12 p.

18. Населення України: імперативи демографрічного старіння. К.: ВД «АДЕФУкраїна», 2014. 288 с. URL: https://idss.org.ua/monografii/2014_Naselennya.pdf

19. Сови Альфред. Старение населения и продление жизни. Методы демографических исследований. М.: Статистика, 1969. C. 70.

20. Іртищева І.О., Гуріна О.В. Методичні підходи до оцінки процесів економічного розвитку регіонів в умовах соціалізації. Соціально-економічні проблеми сучасного періоду України. 2018. Вип. 1. С. 112-118.

21. Іртищева І.О., Гуріна О.В., Работін Ю.А. Методичні підходи до оцінки ефективності регіональної соціальної політики у контексті задоволення суспільних потреб. Вісник ХНАУ ім. В.В. Докучаєва, Серія «Економічні науки». 2018. № 2. С. $247-254$.

22. Kramarenko I. Development of Educational and Social Inclusion in Conditions of Social Transformation of Ukraine. TILTAI. 2015. Vol 72. № 3.P. 83-90.

\section{References:}

1. Kolot, A.M. (2010) Social'no-trudova sfera v umovah global'nyh vyklykiv: tendencii', problemy, mozhlyvosti stijkogo rozvytku [Socio-labor sphere in the context of global challenges: trends, problems, opportunities for sustainable development]. Formation of a market economy: Coll. Science. work, T. 3, p. 9-22.

2. Ekonomichna encyklopedija [Economic Encyclopedia] (2000) Kiev: Publishing Center "Academy"

3. Ljuds'kyj kapital. [Human capital] Wikipedia. https://uk.wikipedia.org/wiki//юдський_капитал.

4. Marx, K. (1978) Kapytal. Krytyka polytycheskoj эkonomyy [Capital. Critique of political economy]. Moskva: Politizdat

5. Castellier, M. (2000) Ynformacyonnaja эpoha: Эkonomyka, obshhestvo y kul'tura. [The information age: economics, society and culture]. Moskva: Mr. un-t. Higher. school economy.

6. Danylyshyn, B.M., Chernyuk, L.G., Fashchevsky, M.I. (2007) Prostorova organizacija produktyvnyh syl Ukrai'ny: mezo- ta mikroregional'nyj riven' [Spatial organization of productive forces of Ukraine: meso- and micro-regional level]. Vinnytsia: Kniga-Vega

7. Degtyareva, I. (2010) Teorii' regional'nogo rozvytku ta i'h evoljucija jak osnova suchasnogo regional'nogo upravlinnja. [Theories of regional development and their evolution as the basis of modern regional governance]. Visn. NADU, vol. 4, pp. 141-148. 
8. Medvid' V.Yu. 2013. Suchasni koncepcii' ta teorii' ekonomichnogo regional'nogo rozvytku [Modern concepts and theories of economic regional development]. Series: Economics and Entrepreneurship, vol. 2 (71), pp. 66-70.

9. Prykhodchenko, T.A. (2016) Teorii' ta koncepcii' regional'nogo rozvytku. [Theories and concepts of regional development]. Electronic scientific professional publication "Effective Economics". № 9. URL: http://www.economy.nayka.com.ua/?op=1\&z=5149

10. Perru, F. (1969) Les quantitative methods de la PR Economic and Society. Paris: Economic

11. Manual on measuring human capital. Prepared by the task force on measuring human capital. (2016). United Nations ECE / CES / 2016/2 / Add.2 Economic Commission for Europe, : https://unstats.un.org/unsd/nationalaccount/consultationDocs/HumanCapitalGuide\%20Global\%20Consultation-v1. pdf

12. Welfare of nations: the role of human and social capital. - OECD (2001) http://www.oecd.org/site/ worldforum / 33703702.pdf

13. Measuring human capital: cutting-edge initiatives and future challenges (2013). United Nations Economic and Social Council, European Economic Commission, Conference of European Statisticians, 61st plenary session, Geneva, 10-12 June 2013, https://www.unece.org/fileadmin/DAM/stats/documents / ece / ces / 2013 / 5_R_.pdf

14. Demografichnyj shhorichnyk «Naselennja Ukrai'ny za 2018 rik» [Demographic yearbook "Population of Ukraine for 2018"] (2018). Kiev: State Statistics Service of Ukraine. http://www.ukrstat.gov.ua/druk/publicat/kat_u/2019/zb/12/zb_ukr_2018.pdf

15. Naselennja Ukrai'ny: imperatyvy demografichnogo starinnja [The population of Ukraine: the imperatives of demographic aging]. (2014) Kiev: VD "ADEFUkraine" https://idss.org.ua/monografii/2014_Naselennya.pdf

16. Demografichni prognozy po Ukrai'ni [Demographic forecasts for Ukraine] (2012) Official website of the MV Ptakhiv Institute of Demography and Social Research of the National Academy of Sciences of Ukraine (section "Developments") http://idss.org.ua/monografii / popforecast2012 . zip.

17. Giampaolo Lanzieri. Grayness of baby boomers: an age-old view of the aging European population. (2011) Eurostat. Statistics in focus, Population and social conditions

18. Naselennja Ukrai'ny: imperatyvy demografichnogo starinnja. [Population of Ukraine: imperatives of demographic aging]. (2014) Kiev: VD "ADEFUkraine". https://idss.org.ua/monografii/2014_Naselennya.pdf

19. Covy Al'fred. (1969) Starenye naselenyja y prodlenye zhyzny. Metodb demografycheskyh yssledovanyj [Aging and prolonging the life of the population. Methods of demographic research]. Moskva: Statistics.

20. Irtyshcheva, I.O., Gurina, O.V. (2018) Metodychni pidhody do ocinky procesiv ekonomichnogo rozvytku regioniv v umovah socializacii' [Methodical approaches to the assessment of the processes of economic development of regions in the conditions of socialization]. Socio-economic problems of the modern period of Ukraine, vol. 1, pp. 112-118.

21. Irtyshcheva, I.O., Gurina, O.V., Rabotin, Y.A. (2018) Metodychni pidhody do ocinky efektyvnosti regional'noi' social'noi' polityky u konteksti zadovolennja suspil'nyh potreb [Methodical approaches to assessing the effectiveness of regional social policy in the context of meeting social needs]. Bulletin of VV Dokuchaeva KhNAU, series "Economic Sciences", vol. 2, pp. 247-254.

22. Kramarenko, I. (2015) Development of educational and social inclusion in the conditions of social transformation of Ukraine. TILTAl, vol. 72. no3, pp. 83-90.

Irtyshcheva Inna Oleksandrivna, Doctor of Economics, Professor, Admiral Makarov National University of Shipbuilding (Mykolayiv, Ukraine)

Trushlyakova Antonina Borysivna, Admiral Makarov National University of Shipbuilding (Mykolayiv, Ukraine)

Ryabets Dmytro Mykolayovych, applicant of the Black Sea Research Institute of Economics and Innovation (Odesa, Ukraine)

Demographic situation of Ukraine in the system of measuring human capital and health care

The purpose of the article is to analyze the demographic situation of Ukraine in the system of measuring human capital and health care. Human capital in scientific theories of socio-economic development is studied. The dynamics of the permanent population of Ukraine for 1991-2018 is analyzed. A regional breakdown of the current population has been made. The dynamics of the coordination load of women per 1000 men for the rural population is analyzed. It is established that the aging of the population of Ukraine can be considered as an indisputable fact and result of objective demographic processes due to long-term structural changes in the age structure of the population towards the predominance of the proportion of people over 60 years. The basis of the age structural pyramid of the population is characterized by the number of children or children. In recent decades, this age group of Ukraine's population has been declining, with the exception of the increase in the birth rate, which was observed in 2002 and intensified in 2005 due to the introduction of state childbirth allowance. But the trend of decreasing the burden of children (0-15 years) and increasing the burden of the elderly (60 years and older) on the population aged 16-59 years and 15-64 years indicates the future continuation of the aging population of Ukraine. Against the background of the obvious trend of decreasing the total population of Ukraine in the near future there will be a continuation of the aging process of the nation, because the current age structure in the future will be reflected in the growth of the proportion of elderly people. The aging of the nation leads to negative economic consequences not only due to the comparative decrease in the share of the working age population, but also due to the increase in pension expenditures. Therefore, significant efforts are needed to overcome the negative transformational processes of demographic structural changes.

Key words: demographic situation, human capital, health care, population

Дата надходження до редакції: 12.11 .2019 p. 